МАТРИЦЫ НАНОПРОВОДОВ

ИЗ АНТИМОНИДА ИНДИЯ И ИХ ПРИМЕНЕНИЯ ДЛЯ ГЕНЕРАЦИИ СВЧ-ИЗЛУЧЕНИЯ

\title{
MATRICES OF INDIUM ANTIMONIDE NANOWIRES AND THEIR APPLICATIONS IN MIICROWAVE GENERATORS
}

\author{
УДК 621.315.592, ВАК 05.27.01, DOI: 10.22184/1993-8578.2017.77.6.96.108
}

\author{
И.Обухов, Г.Горох ${ }^{2,3}$, А.Лозовенко 2 ,Е.Смирнова \\ I.Obukhov', G.Gorokh², 3, A.Lozovenko², E.Smirnova ${ }^{1,4}$
}

\begin{abstract}
Описаны методы изготовления матриц нанопроводов из антимонида индия в регулярных порах анодного оксида алюминия с различными металлическими контактами. Показано, что на основе этих матриц могут быть созданы генераторы электромагнитного излучения терагерцового диапазона частот.

The methods of manufacturing the matrices of the indium antimonide nanowires into regular pores of anodic alumina with various metal contacts on the different substrates have been described. It is shown that on the basis of the matrices of nanowires of indium antimonide may be created generators of electromagnetic radiation of the terahertz frequency range.
\end{abstract}

y никальные свойства антимонида индия (InSb) делают этот материал одним из оптимальных для электроники сверхвысоких частот, ориентированной на низкое энергопотребление [1, 2]. Благодаря малой эффективной массе электронов

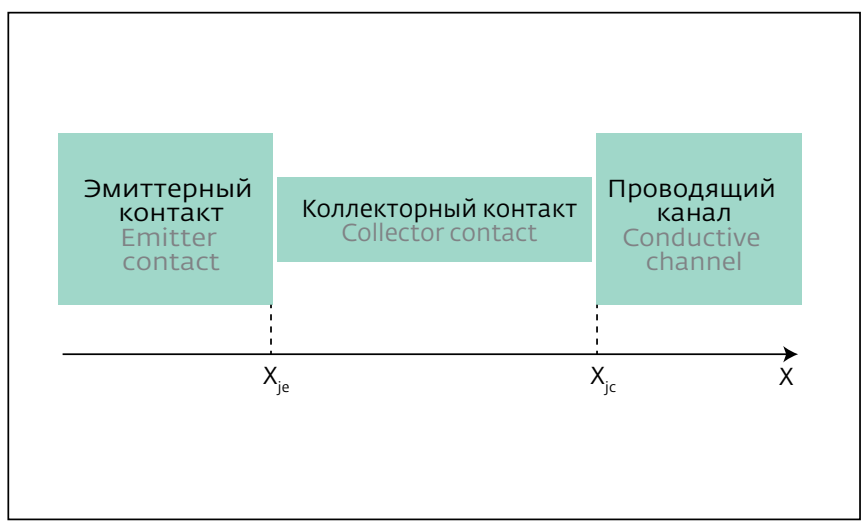

Рис.1. Нанопровод - структура, состоящая из проводящего канала и двух контактов [3]

Fig.1. Nanowire - structure consisting of conductive channel and two contacts [3] проводимости, при комнатной температуре на электрические характеристики структур из InSb с размерами 60 нм и меньше существенно влияет размерное квантование [1, 3].

Современные технологии позволяют формировать в регулярных порах матриц анодного оксида алюминия (AOA) нанопровода из InSb с диаметром от 30 нм [4-8]. Таким образом, имеется возможность использовать на практике размерное квантование энергии электронов в этих объектах.

На рис.1 схематично изображен нанопровод, а на рис.2 показаны характерные потенциальные рельефы для электронов в такой структуре при различных поперечных размерах проводящего канала. Границы контактов с проводящим каналом представляют собой гетеропереходы. Проводящий канал при поперечном сечении $\mathrm{L}_{1}<\mathrm{L}_{\mathrm{dq}}$ оказывается потен ${ }^{-}$ циальным барьером для электронов, высота которого регулируется величиной $\mathrm{L}_{\perp}$. Чем меньше поперечное сечение, тем выше барьер и, соответственно, меньше концентрация электронов в канале [3].

Указанными зависимостями можно воспользоваться для проектирования функциональных

\footnotetext{
НПП "Системные Ресурсы" / Research \& Development Company "System Recourses"

Белорусский государственный университет информатики и радиоэлектроники / Belarusian State University of Informatics and Radioelectronics. Университет ИТМО / ITMO University.

Московский государственный университет им. М.В. Ломоносова / Lomonosov Moscow State University
} 


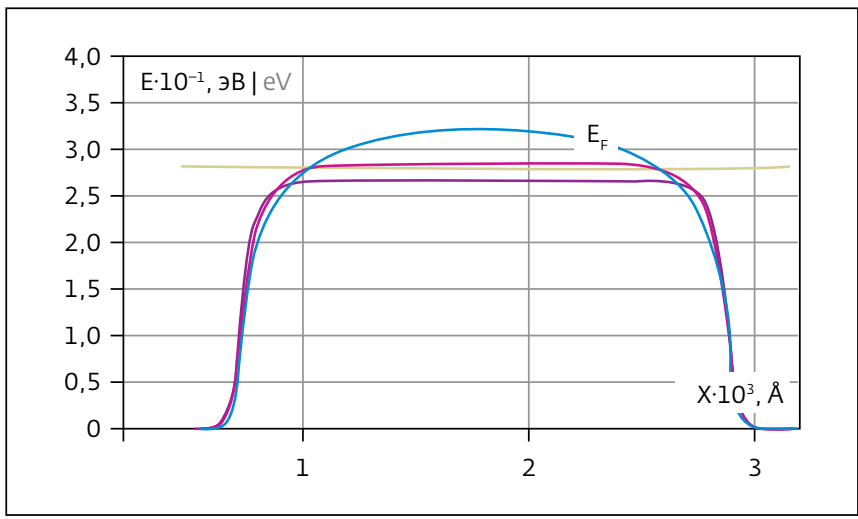

Рис. 2. Потенциальные рельефы для электронов в нанопроводе при нулевом приложенном напряжении, комнатной температуре и различных поперечных размерах проводящего канала $L_{\perp}$ : $1-L_{\perp}=L_{d q} / 2 ; 2-L_{\perp}=L_{d q} / 3 ; 3-L_{\perp}=L_{d q} / 4$. $L_{d q}$ - диина размерного квантования

Fig.2. Potential reliefs for electrons in nanowire at zero applied voltage, room temperature and different cross sectional dimensions of conducting channel $L_{\perp}: 1-L_{\perp}=L_{d q} / 2 ; 2-L_{\perp}=L_{d q} / 3 ; 3-$ $L_{\perp}=L_{d q} / 4 . L_{d q}$ is length of size quantization

электронных устройств на основе нанопроводов. При этом следует учитывать, что протекание тока через гетеропереходы приводит к появлению неравновесных электронов [3], свойства которых положены в основу функционирования рассмотренных ниже приборов.

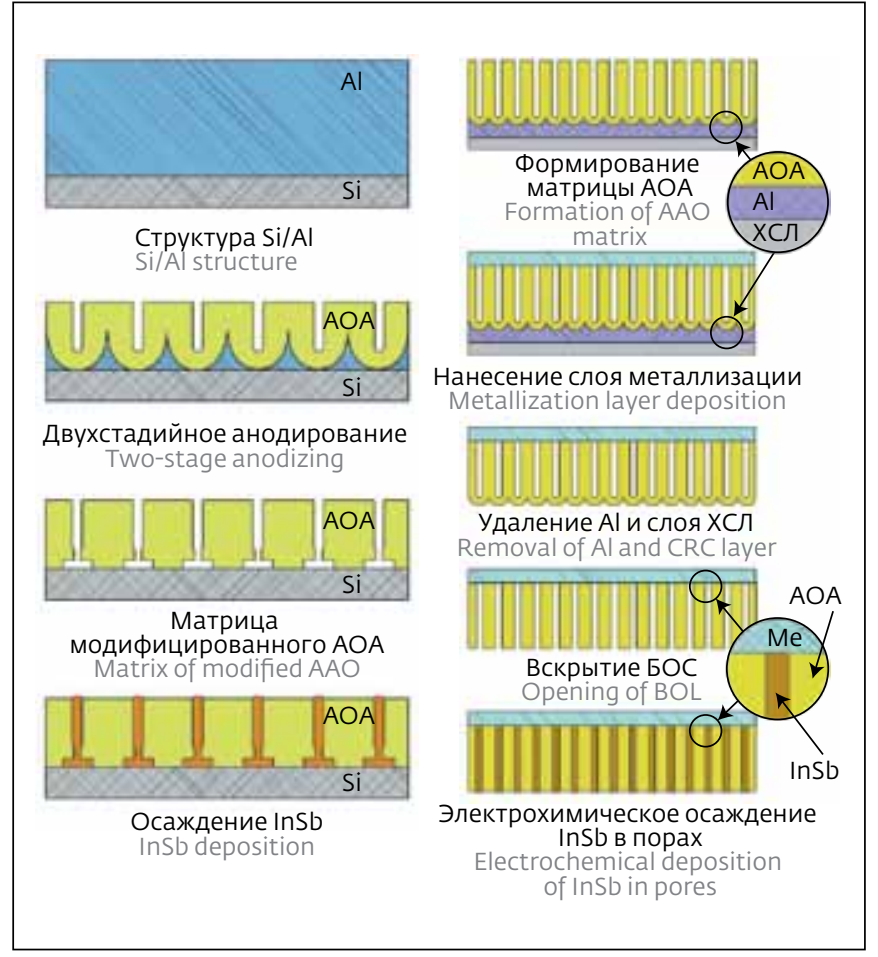

Рис.3. Схематическое изображение последовательности технологических процессов формирования InSb нанопроводов в матрицах AOA на n-Sі подложках (a) и в порах нанопористых подложек из $A O A$ (b)

Fig.3. Schematic representation of sequence of processing for formation of InSb nanowires in AAO matrixes on n-Si substrates (a) and in pores of nanoporous AAO substrates (b)
$\mathbf{T}$ he unique properties of indium antimonide (InSb) make this material one of the most optimal for the microwave electronics, focused on low power consumption $[1,2]$. Owing to the small effective mass of conduction electrons, dimensional quantization affects the electrical characteristics of InSb structures with size of $60 \mathrm{~nm}$ and less at room temperature [1, 3].

Modern technologies allow the formation of InSb nanowires with a diameter of $30 \mathrm{~nm}$ or more in regular pores of anodic aluminum oxide (AAO) matrices [4-8]. Thus, it is possible to use in practice the dimensional quantization of the electron energy in these objects.

Fig.1 shows a schematic representation of a nanowire, and Fig.2 shows the characteristic potential reliefs of electrons in such a structure for different transverse size of the conducting channel. The boundaries of the contacts with the conducting channel are heterojunctions. The conducting channel with a cross section $\mathrm{L}_{1}<\mathrm{L}_{\mathrm{dq}}$ is a potential barrier for electrons whose height is regulated by the quantity of $\mathrm{L}_{\perp}$. The smaller the cross-section, the higher the barrier and, correspondingly, the smaller the electron concentration in the channel [3].

These dependencies can be used to design functional electronic devices based on nanowires. It should be borne in mind that the flow of current through heterojunctions leads to the appearance of nonequilibrium electrons [3], whose properties are the basis for the functioning of the devices considered below.

\section{FORMATION OF NANOWIRES IN MATRIX OF ANODIC ALUMINUM OXIDE}

InSb nanowires in AAO matrices can be formed on glass, dielectric or semiconductor substrates, as well as on free membranes and substrates made of porous aluminium oxide [4-8]. The pore diameters in the AAO matrices and the thickness of the oxide itself are set in advance, based on the technical requirements for the device being created.

The method of preparation of AAO matrices intended for the 


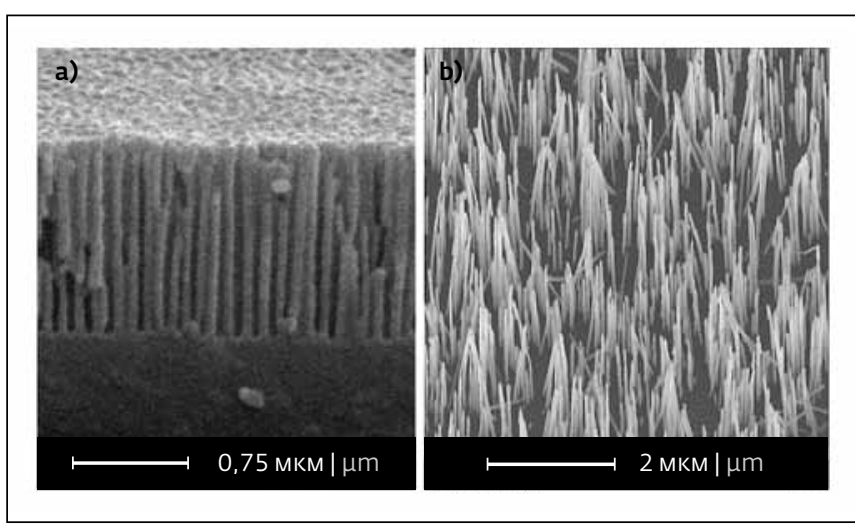

Рис.4. Электронно-микроскопические снимки матриц АОА на кремниевой подложке для формирования матрицы нанопроводов (а) и массива нанопроводов InSb на подложке после селективного удаления матрицы АОА (b)

Fig.4. Electron microscopic images of AAO matrices on silicon substrate for formation of matrix of nanowires (a) and of array of InSb nanowires on substrate after selective removal of AAO matrix (b)

\section{ФОРМИРОВАНИЕ НАНОПРОВОДОВ В МАТРИЦЕ АНОДНОГО ОКСИДА АЛЮМИНИЯ}

Нанопровода из InSb в матрицах AOA могут быть сформированы на стеклянных, диэлектрических или полупроводниковых подложках, а также на свободных мембранах и подложках из пористого оксида алюминия [4-8]. Диаметры пор в матрицах АОА и толщина самого оксида задаются заранее, исходя из технических требований к создаваемому устройству.

Методика приготовления матриц АОА, предназначенных для формирования в них нанопроводов, размер пор, а также технология синтеза проводящих каналов нанопроводов и материал контактов определяют свойства и характеристики матричных структур. На рис. 3 схематично показаны последовательности технологических процессов формирования нанопроводов InSb в порах тонких матриц АOA на кремниевых подложках (рис.За) и в нанопористых подложках из АОА (рис.3b). В последнем случае отношение длины проводящих каналов нанопроводов к их диаметру может достигать тысячи и более.

Электрохимическое осаждение антимонида индия в поры матриц АOA непосредственно на поверхность кремния или на поверхность металлов осуществляется в хлоридном электролите следующего состава: водный раствор $0,1 \mathrm{M} \mathrm{SbCl}_{3}, 0,15 \mathrm{M}$ $\mathrm{InCl}_{3}, 0,36 \mathrm{M}$ лимонная кислота и $0,17 \mathrm{M}$ цитрат калия, доведенный до $\mathrm{pH}=2,0$ 20\%-ным раствором $\mathrm{HCl}$ [9]. Осаждение InSb проводится в комбинированном режиме при переменном токе (50 Гц) с плотностью $8 \mathrm{MA} / \mathrm{cm}^{2}$ в течение трех минут и постоянном токе с плотностью 4 мA/ $\mathrm{cm}^{2}$ в течение 20-50 мин при постоянном перемешивании раствора магнитной мешалкой. Катодный потенциал относительно электрода сравнения (Ag/AgCl) при осаждении на n-Si подложки составляет 1,2-1,7 B, а при осаждении на металл - 0,7-0,9 В. Температуру электролита поддерживают в диапазоне $25 \pm 1^{\circ} \mathrm{C}$.

Такая технология позволяет формировать регулярные массивы нанопроводов с диаметрами от 30 до 70 нм и расстояниями между порами 40-100 нм. Высота матриц может варьироваться от 200 до 50 мкм. "Плотность упаковки" formation of nanowires in them, the pore size, as well as the technology of synthesis of the conducting channels of nanowires and the material of contacts determine the properties and characteristics of matrix structures. Fig. 3 schematically shows the sequence of processes for the formation of InSb nanowires in the pores of thin AAO matrices on silicon substrates (Fig.3a) and in nanoporous AAO substrates (Fig.3b). In the latter case, the ratio of the length of the conducting channels of nanowires to their diameter can reach thousands or more.
The electrochemical deposition of indium antimonide into the pores of the AAO matrices directly to the silicon surface or to the metal surface is carried out in a chloride electrolyte of the following composition: an aqueous solution of $\mathrm{SbCl}_{3}(0.1 \mathrm{M}), \mathrm{InCl}_{3}(0.15 \mathrm{M})$, citric acid $(0.36 \mathrm{M})$ and potassium citrate $(0.17 \mathrm{M})$ adjusted to $\mathrm{pH}=$ 2.0 with a $20 \%$ solution of $\mathrm{HCl}$ [9]. InSb deposition is carried out in a combined mode with alternating current $(50 \mathrm{~Hz})$ with a density of $8 \mathrm{~mA} / \mathrm{cm}^{2}$ within $3 \mathrm{~min}-$ utes and with constant current with a density of $4 \mathrm{~mA} / \mathrm{cm}^{2}$ within 20-50 minutes with constant stirring of the solution by a magnetic stirrer. The cathode potential with respect to the reference electrode $(\mathrm{Ag} / \mathrm{AgCl})$ when deposited on the n-Si substrate is 1.2$1.7 \mathrm{~V}$, and when deposited on the metal - 0.7-0.9 V. The electrolyte temperature is maintained in the range of $25 \pm 1^{\circ} \mathrm{C}$.

This technology allows the formation of regular arrays of nanowires with diameters from $30 \mathrm{~nm}$ to $70 \mathrm{~nm}$ and distances between pores of $40-100 \mathrm{~nm}$. The height of the matrices can vary from $200 \mathrm{~nm}$ to $50 \mu \mathrm{m}$. The "packing density" of nanowires is $10^{10}-10^{11}$ wires $/ \mathrm{cm}^{2}$, and the characteristic 
нанопроводов составляет $10^{10} 10^{11}$ проводов/см ${ }^{2}$, а характерная площадь сечения проводящих каналов $-10^{11} \mathrm{CM}^{2}$.

Электронно-микроскопические снимки матриц АОА на кремниевой подложке для осаждения нанопроводов, а также массив нанопроводов на подложке после селективного растворения матрицы АОА представлены на рис.4. На рис.5 показаны электронные микрофотографии подложки из АОА с нанопроводами InSb и сами нанопровода после селективного растворения подложки.

Методом электронно-зондового рентгеноспектрального микроанализа были проведены исследования состава InSb-нанопроводов. Удалось определить, что в весовом выражении индий составляет $36,89 \%$, а сурьма - $63,11 \%$. Атомарное же соотношение этих элементов в составе наноструктур несколько иное - $38,26 \%$ In и $61,74 \%$ Sb. Полученные данные свидетельствуют о том, что InSb в нанопроводах находится в поликристаллическом состоянии $[10,11]$.

Важную роль в функционировании приборов на основе матриц нанопроводов играют переходы между контактными областями и проводящим каналом. Были сформированы контакты из различных материалов (никеля, меди и алюминия) и проведены измерения вольтамперных характеристик (BAX) матриц нанопроводов InSb в AOA. Методика измерений описана в работе [11].

На рис.6 показаны ВАХ матриц нанопроводов InSb с контактами из никеля и меди. BAX структур с контактами из никеля, представленные на рис.6а, имели нелинейный вид, на них

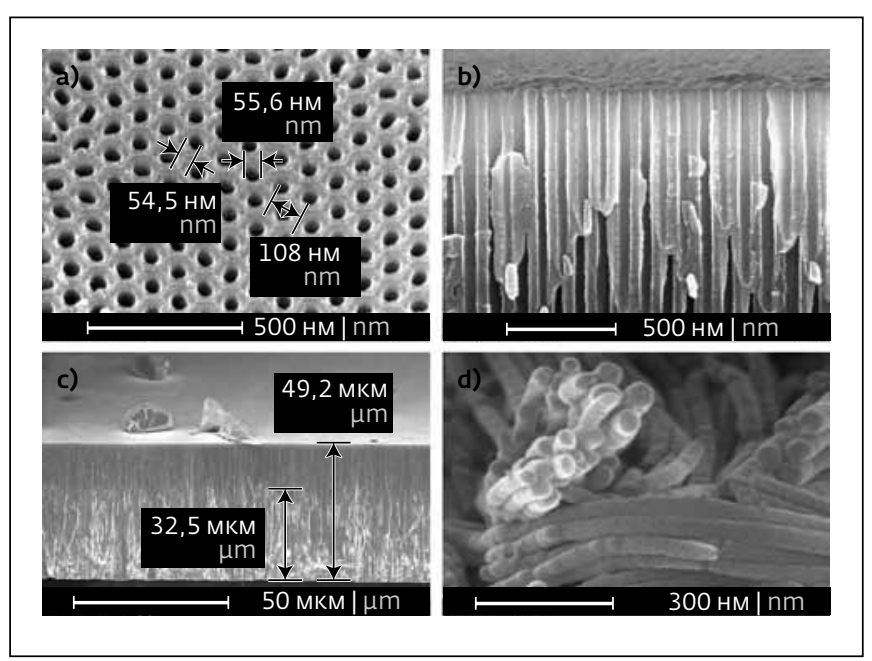

Рис.5. Электронно-микроскопические снимки поверхности (a) и поперечного сечения матриц AOA (b), сечения подложки с осажденными InSb нанопроводами (c) и нанопроводов InSb после селективного удаления подиожки AOA (d)

Fig.5. Electron microscopic images of surface (a) and cross section of AAO matrices (b), substrate cross section with deposited InSb nanowires (c), and InSb nanowires after selective removal of AAO substrate (d)

по степени нелинейности можно выделить три участка. Первый характеризуется слабой нелинейной зависимостью тока от напряжения: ток растет от 0 до 5 мА при увеличении напряжения от 0 В до порогового значения 3-3,5 В. На втором участке при дальнейшем росте напряжения до 4-4,5 В коэффициент нелинейности становится максимальным, cross-sectional area of conducting channels is $10^{-11} \mathrm{~cm}^{2}$.

Electron microscopic images of AAO matrices on a silicon substrate for the deposition of nanowires, as well as an array of nanowires on a substrate after selective dissolution of the AAO matrix are shown in Fig.4. Fig. 5 shows electron images of AAO substrate with InSb nanowires and nanowires themselves after selective dissolution of the substrate.

Using the electron-probe X-ray spectral microanalysis, the composition of InSb nanowires was studied. It was determined that in terms of weight, indium's share is
$36.89 \%$, and the share of antimony is $63.11 \%$. Atomic ratio of these elements in the composition of nanostructures is somewhat different $38.26 \%$ In and $61.74 \% \mathrm{Sb}$. The data obtained indicate that InSb is in the polycrystalline state in nanowires $[10,11]$.

Important role in the functioning of devices based on nanowire arrays is played by transitions between contact areas and a conducting channel. Contacts were formed from various materials (nickel, copper, aluminum), and measurements of the currentvoltage characteristics of InSb nanowire matrices in AAO were performed. The measurement procedure is described in [11].

Fig. 6 shows the current-voltage characteristics of InSb nanowire matrices with nickel and copper contacts. The current-voltage characteristic of structures with nickel contacts, presented in Fig.6a, had a nonlinear appearance, three sections can be distinguished in them by the degree of nonlinearity. The first is characterized by a weak nonlinear current dependence on the voltage: the current rises from $0 \mathrm{~mA}$ to $5 \mathrm{~mA}$ with an increase in voltage from $0 \mathrm{~V}$ to a threshold value of 3-3.5 V. In the second section, with a further increase in 


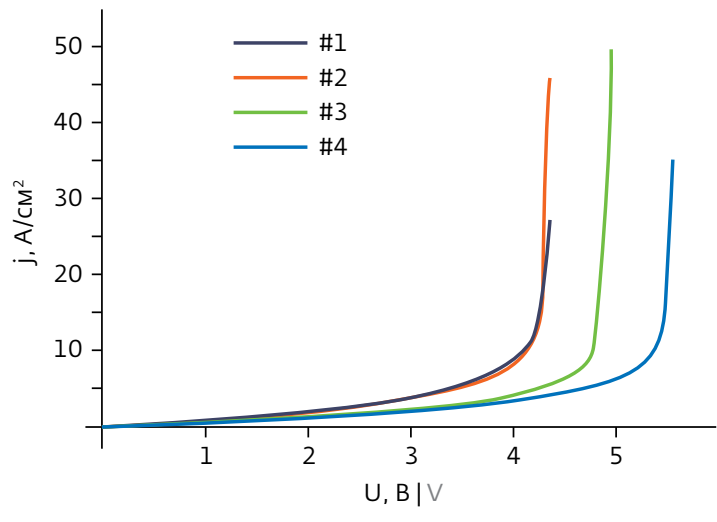

a)

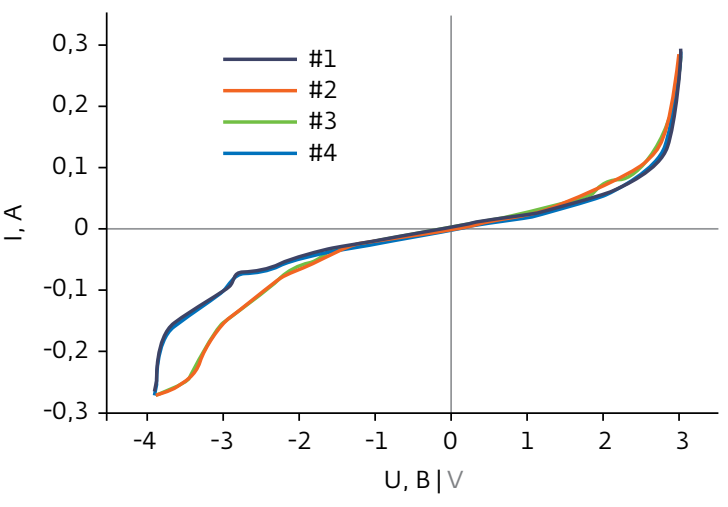

b)

Puc.6. BAX матрицы нанопроводов InSb с контактами из никеля (a) и меди (b) [1]]

Fig.6. VAC of matrix of InSb nanowires with nickel (a) and copper (b) contacts [1]]

ток ускоренно возрастает до 15-20 мА. На третьем участке при незначительном приращении напряжения ток возрастает до своего максимального значения, при этом плотность тока через контакт, соединяющий около $1,025 \cdot 10^{8}$ нанопроводов, составила $27,18 \mathrm{~A} / \mathrm{cm}^{2}$. Несмотря на то, что измеренные на разных контактах ВАХ имели одинаковый вид, границы обозначенных участков изменялись в пределах $\pm 0,5$ B.

На ВАХ матриц с контактами из меди после первых включений произошла приработка контактных переходов InSb/Cu. BAX имели стабильный вид с экспоненциальной зависимостью тока от изменяющихся напряжений при прямом и обратном включениях (рис.6b). Токи через нанопровода достигали 320 мА и были стабильны во времени, что соответствовало плотности тока 129,8 A/см². На некоторых образцах наблюдались ВАХ с гистерезисом, который пропадал после проведения нескольких серий измерений. Это явление связано, по-видимому, с наличием окиси и закиси меди и миграцией кислорода в приконтактном слое матрицы [11].

BAX структуры с алюминиевыми контактами имели вид, похожий на ВАХ структуры с медными voltage to $4-4.5 \mathrm{~V}$, the nonlinearity coefficient becomes maximum, and the current rise to $15-20 \mathrm{~mA}$. In the third section, with an insignificant increase in the voltage, the current rises to its maximum value, while the current density through the contact connecting about $1,025 \cdot 10^{8}$ nanowires was $27.18 \mathrm{~A} / \mathrm{cm}^{2}$. Despite the fact that the CVC measured at different contacts had the same form, the boundaries of the designated sections varied within $\pm 0.5 \mathrm{~V}$.

On the CVC of matrices with copper contacts, after the first connection, the preaging of contact transitions of InSb/Cu occurred. The
CVCs were stable with the exponential dependence of the current on the varying voltages for forward and reverse connection (Fig.6b). The currents through the nanowires reached $320 \mathrm{~mA}$ and were stable in time, which corresponded to a current density of $129.8 \mathrm{~A} / \mathrm{cm}^{2}$. On some samples, an CVC with a hysteresis was observed, which disappeared after several series of measurements. This phenomenon is apparently connected with the presence of oxide and cuprous oxide and migration of oxygen in the contact layer of the matrix [11].

The CVC of the structure with aluminum contacts looked similar to the current-voltage characteristic of the copper contact structure shown in Fig.6b. The current density in such structures was about $100 \mathrm{~A} / \mathrm{cm}^{2}$. There were kinks on the characteristic, which can be explained by heating the sample.

Experiments on samples with gold contacts continue to this day. They give hope for obtaining current densities close to $10^{4}-10^{5} \mathrm{~A} / \mathrm{cm}^{2}$, which were calculated in [1] and measured for a single InSb nanowire by the authors of [12]. Obtaining high current densities will indicate sufficient perfection of the investigated structures and the possibility of 
контактами, представленной на рис.6b. Плотность тока в таких структурах составляла около $100 \mathrm{~A} / \mathrm{cm}^{2}$. На характеристике имелись изломы, которые могут быть объяснены нагревом образца.

Эксперименты на образцах с контактами из золота продолжаются до настоящего времени. Они дают надежду на получение плотностей тока близких к $10^{4}-10^{5} \mathrm{~A} / \mathrm{cm}^{2}$, которые были рассчитаны в работе [1] и измерены для единичного нанопровода из InSb авторами работы [12]. Получение высоких плотностей токов будет свидетельствовать о достаточном совершенстве исследуемых структур и о возможности реализации на их основе предлагаемых ниже приборных конструкций.

\section{РЕЛАКСАЦИОННАЯ НЕУСТОЙЧИВОСТЬ И ГЕНЕРАЦИЯ СВЧ-КОЛЕБАНИЙ}

При определенных условиях в контактных областях нанопровода могут возникнуть релаксационная неустойчивость и затухающие осцилляции концентрации электронов [3]. Оба эти явления имеют пороговый характер и возможны только, если подвижности электронов в контактах и проводящем канале нанопровода различны.

Для определенности будем считать, что подвижность электронов в проводящем канале нанопровода больше их подвижностей в эмиттерном и коллекторном контактах. Такое допущение оправдано для нанопроводов из InSb c контактами из других полупроводниковых материалов или из металлов. Тогда при положительном смещении между коллектором и эмиттером релаксационная неустойчивость может наблюдаться в коллекторном контакте, а осцилляции концентрации электронов - в эмиттерном контакте.

Релаксационная неустойчивость развивается, если плотность тока в нанопроводе ј превышает пороговое значение $j_{\text {ins }}$. Причиной возникновения неустойчивости является слишком большая при $\mathrm{j}>\mathrm{j}_{\text {ins }}$ скорость неравновесных электронов, попадающих из проводящего канала нанопровода в коллекторный контакт. Они не успевают релаксировать к состоянию термодинамического равновесия за время пролета длины релаксации и накапливаются в контактной области.

Согласно расчетам [3] концентрация электронов в эмиттерном контакте экспоненциально нарастает с инкрементом порядка 40 ТГц при комнатной температуре. При достижении некоторого предельного значения концентрации $[13,14]$ ее нарастание сменяется экспоненциально быстрым затуханием с декрементом того же порядка, либо происходит тепловой пробой. Для нанопроводов с коротким каналом [3] и невысокой собственной концентрацией электронов в коллекторном контакте релаксационная неустойчивость должна приводить к заметным изменениям в проводимости структуры.

Если плотность тока в нанопроводе превышает другое пороговое значение $\mathrm{j}_{\text {osc }}$, в эмиттерном контакте возникают затухающие высокочастотные осцилляции концентрации электронов [3]. Причиной осцилляций является недостаточная концентрация электронов, необходимых для implementing on their basis the proposed device designs.

\section{RELAXATION INSTABILITY AND GENERATION OF MICROWAVE OSCILLATIONS}

Under certain conditions, relax ation instabilities and damped oscillations of the electron concentration can arise in the contact regions of the nanowire [3]. Both of these phenomena have a threshold character and are possible only if the electron mobilities in the contacts and the conducting channel of the nanowire are different.

For definiteness, we will assume that the mobility of electrons in the conducting channel of the nanowire is greater than their mobilities in the emitter and collector contacts. This assumption is justified for InSb nanowires with contacts made of other semiconductor materials or metals. Then, with a positive displacement between the collector and the emitter, the relaxation instability can be observed in the collector contact, and the oscillations of the electron concentration - in the emitter contact.

Relaxation instability develops if the current density in the nanowire $\mathrm{j}$ exceeds the threshold value $\mathrm{j}_{\text {ins }}$. The cause of the instability is the velocity (too high for $\mathrm{j}>\mathrm{j}_{\text {ins }}$ ) of nonequilibrium electrons that come from the conductive channel of the nanowire to the collector contact. They do not have time to relax to the state of thermodynamic equilibrium during the time of flight of the relaxation length, and accumulate in the contact area.

According to the calculations of [3], the electron concentration in the emitter junction increases exponentially with an increment of the order of $40 \mathrm{THz}$ at room temperature. When a certain limiting concentration $[13,14]$ is reached, its growth is replaced by 


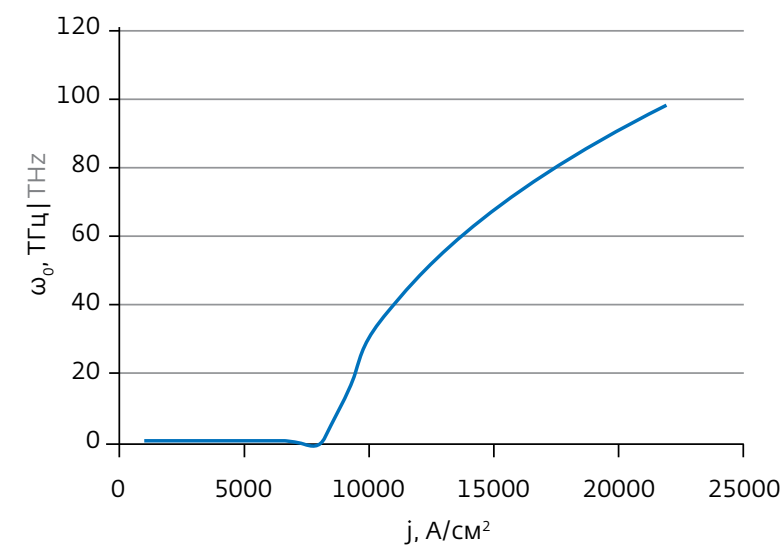

Рис.7. Частота осциляяций концентрации электронов в эмиттере $\omega_{0}$ как функция плотности тока ј [14]

Fig.7. Oscillation frequency of electron concentration in emitter $\omega_{0}$ as function of current densityj [14]

обеспечения в стационарном режиме требуемого уровня их инжекции из эмиттера в проводящий канал нанопровода.

В общем случае пороговые плотности токов $j_{\text {ins }}$ и $\mathrm{j}_{\text {osc }}$ - разные величины. Однако, варьируя параметры нанопровода, можно добиться того, что оба рассматриваемых явления начнут развиваться при одном и том же значении плотности тока [14]. При этом, как видно на рис.7, в эмиттере появляется встроенная индуктивность, а в коллекторе, как показано на рис.8, формируется область

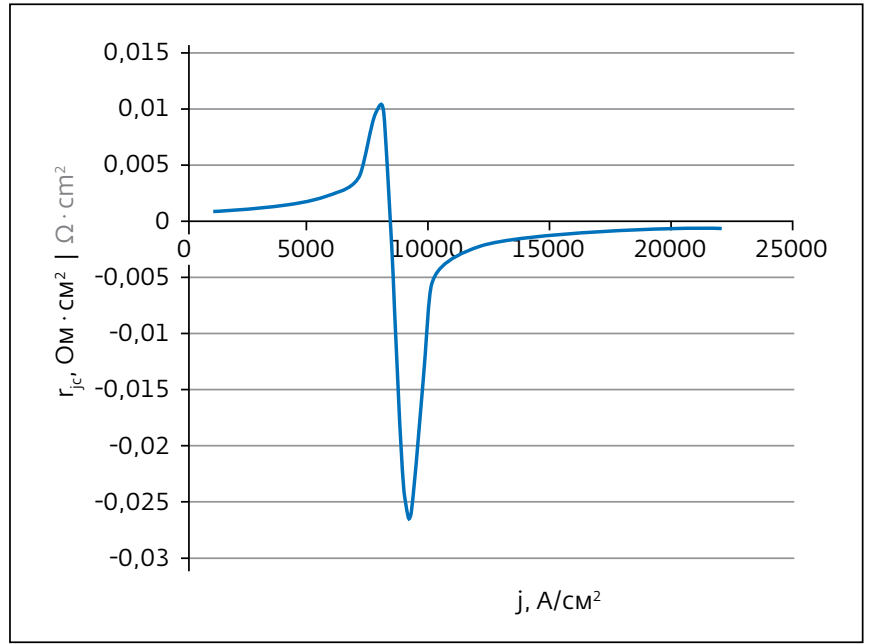

Рис.8. Дифференциальное сопротивление перехода между проводящим каналом и коллектором гјс как функция плотности тока ј [14]

Fig.8. Differential resistance of transition between conductor channel and collector ric as function of current density j [14]

с отрицательным дифференциальным сопротивлением. То есть возникают условия, необходимые для генерации СВЧ-мощности.

Анализ соотношений, полученных в работах [3, $13,14]$, показывает, что генерация СВЧ-колебаний в квантовом проводе возможна только при определенных соотношениях между его геометрическими и электрофизическими параметрами. Представленные на рис.7-9 результаты были рассчитаны для нанопровода с проводящим каналом an exponentially fast decay with a decrement of the same order, or a thermal breakdown occurs. For nanowires with a short channel [3] and a low intrinsic electron concentration in the collector contact, the relaxation instability should lead to appreciable changes in the conductivity of the structure.

If the current density in the nanowire exceeds another threshold value $j_{\text {osc }}$, damped high-frequency oscillations of the electron concentration appear in the emitter contact [3]. The reason for the oscillations is the inadequate concentration of electrons necessary to ensure, in a stationary mode, the required level of their injection from the emitter into the conducting channel of the nanowire.

In general, the threshold densities of $j_{\text {ins }}$ and $j_{\text {osc }}$ are different. However, by varying the parameters of the nanowire, it can be achieved that both of the considered phenomena will begin to develop at the same current density value [14]. In this case, as seen in Fig.7, an inductance appears in the emitter, and in the collector, as shown in Fig.8, a region with a negative differential resistance is formed. That is, the conditions necessary for generating microwave power arise.
Analysis of the relationships obtained in $[3,13,14]$ shows that the generation of microwave oscillations in a quantum wire is possible only for certain relations between its geometric and electrophysical parameters. The results presented in Fig.7-9 were calculated for a nanowire with InSb conductor channel of $100 \mathrm{~nm}$ in length and silicon contacts of n-type. The length of the emitter contact was also $100 \mathrm{~nm}$, and the electron concentration - $10^{14}$ $\mathrm{cm}^{3}$. The length of the collector contact was $500 \mathrm{~nm}$, and the electron concentration $-5 \cdot 10^{14} \mathrm{~cm}^{3}$.

Calculation of the maximum power generating by such 


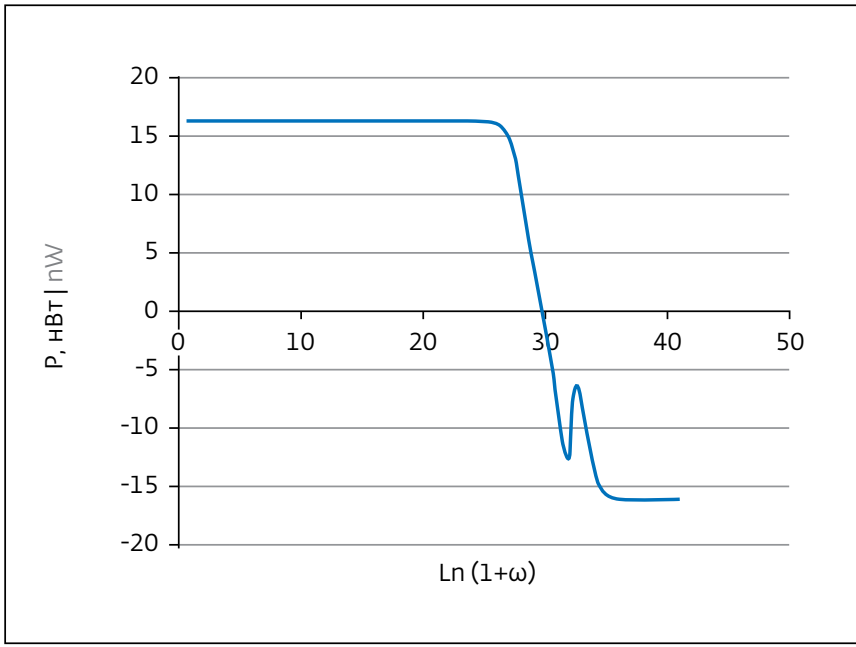

Pис.9. Максимальная СВЧ-мощность, генерируемая одним нанопроводом [14]

Fig.9. Maximum microwave power generated by single nanowire [14]

из InSb длиной 100 нм и кремниевыми контактами n-типа. Длина эмиттерного контакта равнялась также 100 нм, а концентрация электронов - $10^{14} \mathrm{~cm}^{3}$. Длина коллекторного контакта составляла 500 нм, а концентрация электронов $-5 \cdot 10^{14} \mathrm{CM}^{3}$.

Расчет максимальной мощности, отдаваемой таким нанопроводом во внешнюю цепь, представлен на рис.9. При частотах, меньших 1,4 ТГц, он может генерировать порядка 10 нВт СВЧ-мощности. При этом его расчетный КПД равен около 13\%. При

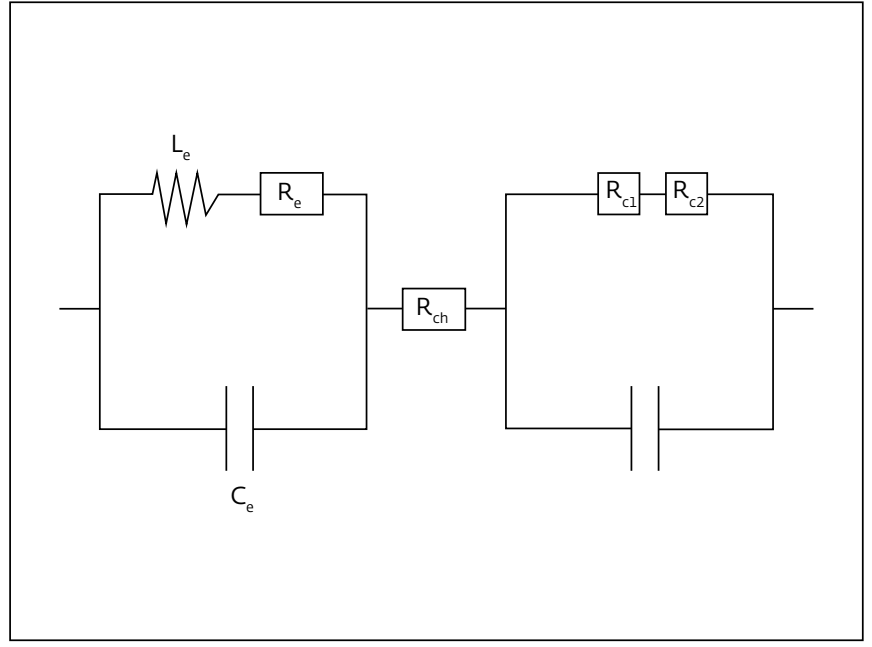

Pис.10. Схема замещения матрицы нанопроводов

Fig.10. Equivalent circuit for matrix of nanowires

частотах, превышающих 7,2 ТГц, генерация прекращается, и квантовый провод поглощает внешнюю энергию [13, 14].

\section{СХЕМА ЗАМЕЩЕНИЯ}

Электрическая схема замещения для матрицы нанопроводов показана на рис.10. Она состоит из следующих элементов: эмиттер (сопротивление $\mathrm{R}_{\mathrm{e}}$, емкость $\mathrm{C}_{\mathrm{e}}$, индуктивность $\mathrm{L}_{\mathrm{e}}$ ), область проводящих каналов (сопротивление $\mathrm{R}_{\mathrm{ch}}$ ), коллектор (сопротивления $\mathrm{R}_{\mathrm{cl}}$ и $\mathrm{R}_{\mathrm{c} 2}$, емкость $\mathrm{C}_{\mathrm{c}}$ ).

Все параметры являются функциями тока и вычисляются на основе результатов a nanowire to the external circuit is shown in Fig.9. At frequencies below $1.4 \mathrm{THz}$, it can generate about $10 \mathrm{nW}$ of microwave power. At the same time, its estimated efficiency is about $13 \%$. At frequencies exceeding $7.2 \mathrm{THz}$, the generation ceases and the quantum wire absorbs external energy $[13,14]$.

\section{EQUIVALENT CIRCUIT}

The electrical equivalent circuit for the matrix of nanowires is shown in Fig.10. It consists of the following elements: emitter (resistance $\mathrm{R}_{\mathrm{e}}$, capacity $\mathrm{C}_{\mathrm{e}}$, inductance $\mathrm{L}_{\mathrm{e}}$ ), region of conducting channels (resistance $\mathrm{R}_{\mathrm{ch}}$ ), collector (resistances $\mathrm{R}_{\mathrm{c} 1}$ and $\mathrm{R}_{\mathrm{c} 2}$, capacitance $\mathrm{C}_{\mathrm{s}}$ ).

All parameters are current functions and are calculated on the basis of simulation results of charge transfer in the nanowire, taking into account the existence of instability and relaxation modes. The resistances of $R_{e}$ and $\mathrm{R}_{\mathrm{cl}}$ are the usual ohmic resistances of the emitter and collector, positive for all current values. The resistance $R_{c 2}$ is positive for currents less than the relaxation instability threshold, and becomes negative when the current exceeds the threshold value. The value of $\mathrm{R}_{\mathrm{c} 2}$ is determined by the damping decrement or the growth increment of electron concentration fluctuations in the collector. The $\mathrm{L}_{\mathrm{e}}$ inductance equals zero at currents less than the threshold of relaxation oscillations and is determined by their frequency when the current exceeds the threshold value.

To take into account the effect of the microwave electric field of the resonator on the processes in the semiconductor structure, the oscillator circuit must be supplemented by an oscillatory circuit. Therefore, numerical calculations were carried out with an oscillatory circuit (Fig.11), taking into account the basic design features 


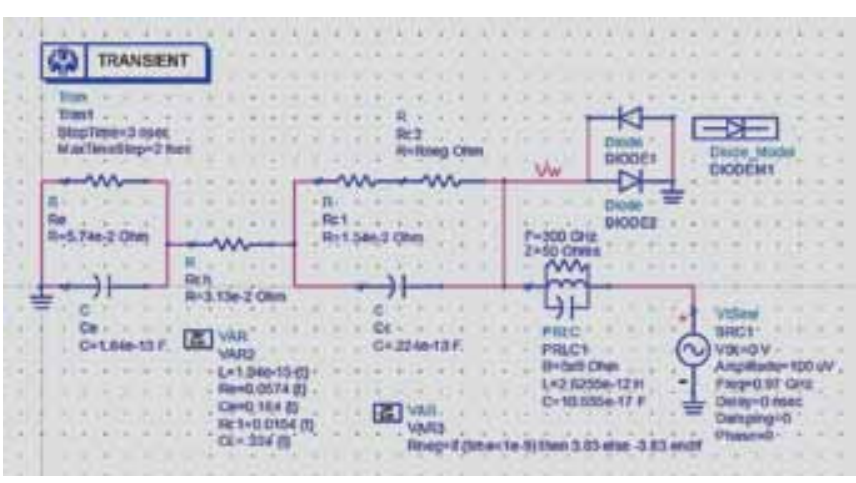

Puc.11. Схема замещения генератора с учетом конструкции корпуса

Fig.11. Equivalent circuit of generator taking into account the hull design

моделирования переноса заряда в нанопроводе с учетом наличия режимов неустойчивости и релаксационных колебаний. Сопротивления $\mathrm{R}_{\mathrm{e}}$ и $\mathrm{R}_{\mathrm{cl}}$ - это обычные омические сопротивления эмиттера и коллектора, положительные при всех значениях тока. Сопротивление $\mathrm{R}_{\mathrm{c} 2}$ положительно при токах, меньших порога релаксационной неустойчивости, и становится отрицательным при превышении током порогового значения. Значение $\mathrm{R}_{\mathrm{c} 2}$ определяется декрементом затухания или инкрементом нарастания флуктуаций концентрации электронов в коллекторе. Индуктивность $\mathrm{L}_{\mathrm{e}}$ равняется нулю при токах меньших порога релаксационных колебаний и определяется их частотой при превышении током порогового значения.
Для учета влияния электрического СВЧ-поля резонатора на процессы в полупроводниковой структуре цепь генератора должна быть дополнена колебательным контуром. Поэтому численные расчеты проводились с колебательным контуром (рис.11), учитывающим основные конструктивные особенности электродинамической системы генератора.

В этой схеме диоды, подключенные навстречу друг другу, играют роль ограничителя частоты, а колебательный контур замещает комбинирован ную колебательную систему, образованную коаксиальной цепью структуры и подключенным к ее резонаторной камере регулируемым волноводным резонатором.

\section{МОДЕЛИРОВАНИЕ}

При моделировании выполнялась оптимизация численных значений элементов схемы замещения. Рабочая точка выбиралась так, чтобы инкремент нарастания флуктуаций концентрации электронов в коллекторе соответствовал терагерцовому диапазону частот. В результате выбран ток, равный 4,10 A. Параметры цепи при этом токе оказываются следующими: $\mathrm{R}_{\mathrm{e}}=0,0574 \mathrm{OM}, \mathrm{C}_{\mathrm{e}}=0,184 \Pi \Phi, \mathrm{L}_{\mathrm{e}}=0,00 \Gamma \mathrm{H}$, $\mathrm{R}_{\mathrm{c} 1}=0,0154 \mathrm{OM}, \mathrm{R}_{\mathrm{c} 2}=3,83$ Ом, $\mathrm{C}_{\mathrm{c}}=0,224 \Pi \Phi, \mathrm{R}_{\mathrm{ch}}=$ 0,0313 Oм.

Расчеты характеристик генератора в корпусе показали, что индуктивность эмиттера затрудняет переход прибора в режим генерации. По этой причине у активного элемента эмиттер выполнен из золота, а не из кремния. В таком случае of the electrodynamic system of the generator.

In this circuit, the diodes connected toward each other play the role of a frequency limiter, and the oscillatory circuit replaces the combined oscillatory system formed by the coaxial circuit of the structure and by the adjustable waveguide resonator connected to its resonator chamber.

\section{MODELING}

During the simulation, the numerical values of the elements of the equivalent circuit were optimized. The operating point was chosen so that the growth increment of the electron concentration fluctuations in the collector corresponded to the terahertz frequency range. As a result, a current of $4.10 \mathrm{~A}$ is selected. The circuit parameters at this current turn out to be: $\mathrm{R}_{\mathrm{e}}=0.0574 \mathrm{Ohm}$, $\mathrm{C}_{\mathrm{e}}=0.184 \mathrm{pF}, \mathrm{L}_{\mathrm{e}}=0.00 \mathrm{H}, \mathrm{R}_{\mathrm{c} 1}=$ 0.0154 Ohm, $\mathrm{R}_{\mathrm{c} 2}=3.83 \mathrm{Ohm}, \mathrm{C}_{\mathrm{c}}=$ $0.224 \mathrm{pF}, \mathrm{R}_{\mathrm{ch}}=0.0313 \mathrm{Ohm}$.

Calculations of the characteristics of the generator in the housing showed that the inductance of the emitter makes it difficult for the device to go into the generation mode. For this reason, the emitter of the active element is made of gold, and not of silicon. In this case, relaxation oscillations in the emitter contact can occur only at very high currents, several orders of magnitude higher than the threshold current of the relaxation instability in the collector.

The trigger pulse was selected with an amplitude of $0.1 \mathrm{~V}$ at a frequency of $0.97 \mathrm{GHz}$. The inductance and capacitance of the external oscillatory circuit varied within $2.63-0.56 \mathrm{pH}, 0.105-$ $0.022 \mathrm{fF}$. As a result, excitation of oscillations at frequencies from $303 \mathrm{GHz}$ to $994.7 \mathrm{GHz}$ was provided. Fig.12 and Fig.13 show the calculated dependences of the voltage of the generated signal 


\section{NANOTECHNOLOGY}

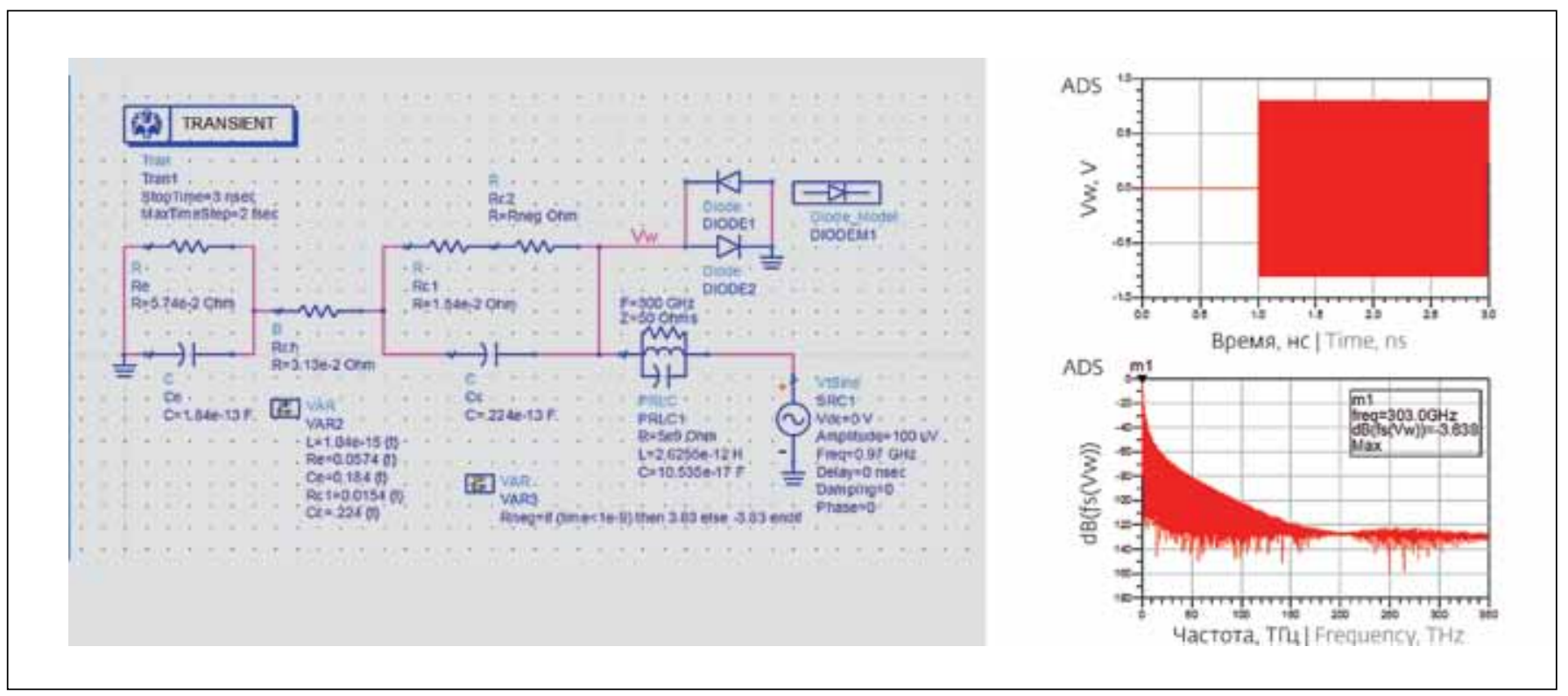

Puc.12. Генерация на частоте 303,0 ГГи

Fig.12. Generation at frequency of $303.0 \mathrm{GHz}$

релаксационные колебания в эмиттерном контакте могут проявиться только при очень больших токах, на несколько порядков превышающих пороговый ток релаксационной неустойчивости в коллекторе.

Импульс запуска выбирался с амплитудой 0,1 В на частоте 0,97 ГГц. Индуктивность и емкость внешнего колебательного контура изменялись в пределах 2,63 0,56 пГн, 0,105 0,022 фФ. В результате обеспечивалось возбуждение колебаний на частотах от 303 до 994,7 ГГц. На рис.12 и 13 представлены рассчитанные зависимости напряжения генерируемого сигнала от времени и спектры сигналов на этих частотах. Численное моделирование показало, что при включении генератор запускается "жестко", амплитуда колебаний достигает стационарного значения $\mathrm{U}_{\mathrm{w}}=0,8 \mathrm{~B}$ за первую половину периода колебаний, доступная выходная мощность составляет 12,8 мВт.

СВЧ-генератор как эквивалентный четырехполюсник может быть описан S-параметрами, измеряемыми в линиях с согласованными нагрузками, что на сверхвысоких частотах реализуется наиболее on time and the spectra of the signals at these frequencies. Numerical simulation showed that, when turned on, the generator starts "hard", the amplitude of the oscillations reaches a stationary value $U_{w}=0.8 \mathrm{~V}$ for the first half of the oscillation period, the available output power is $12.8 \mathrm{~mW}$.

The microwave generator as an equivalent four-terminal network can be described by S-parameters measured in lines with matched loads, which is realized most simply at the ultrahigh frequencies. Using S-parameters of the generator measured at several frequencies, it is possible to determine (or refine) the elements of its equivalent circuit, and conversely, the known equivalent circuit allows calculating S-parameters at any frequency of the range in which this circuit is correct.

To calculate the S-parameters of the microwave generator with matrix of nanowires as the active element, the EMPro software was used. The results are shown in Figs.14 and 15. The reflection coefficient (S11) reaches the minimum value at a frequency of $650 \mathrm{GHz}$. At the same frequency, the transmission factor (S12) has a quite acceptable value of about $10 \mathrm{~dB}$. Also there are local minima of S11 parameter at frequencies $300 \mathrm{GHz}$, $370 \mathrm{GHz}, 910 \mathrm{GHz}$, etc.

Based on the analysis of the dependence of the S-parameters of the generator on frequency, it can be concluded that the frequencies of $300 \mathrm{GHz}, 370 \mathrm{GHz}, 650 \mathrm{GHz}$ and $910 \mathrm{GHz}$ are optimal for its operation. At these frequencies, the reflection coefficient has minima, the transmission coefficient - local maxima, and the VSWR takes values in the range from 4 to 15.

Fig.16 shows the distribution of the electric field $\mathrm{E}$ in the waveguide at selected frequencies. At a frequency of $300 \mathrm{GHz}$, the largest part of the power goes out in 


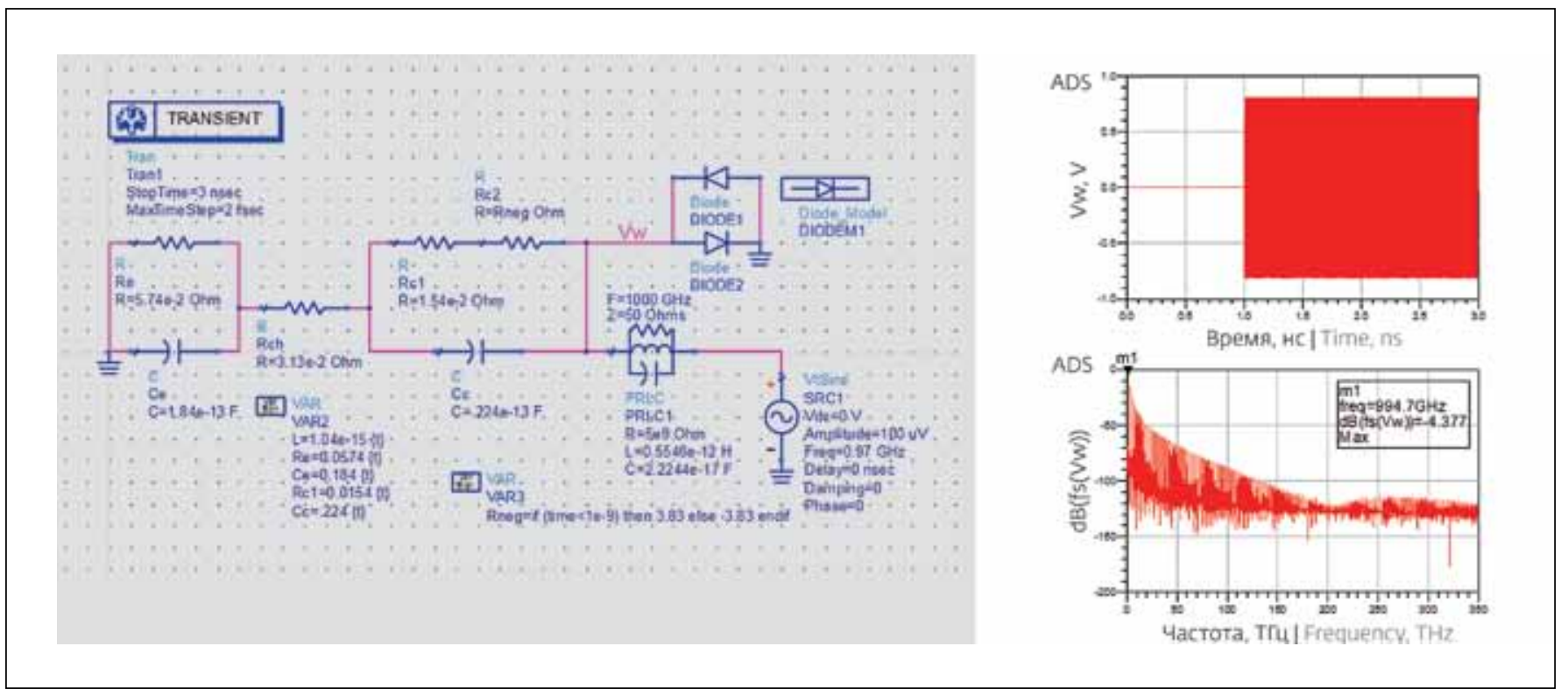

Puc.13. Генерация на частоте 994,7 ГГи

Fig.13. Generation at frequency of $994.7 \mathrm{GHz}$
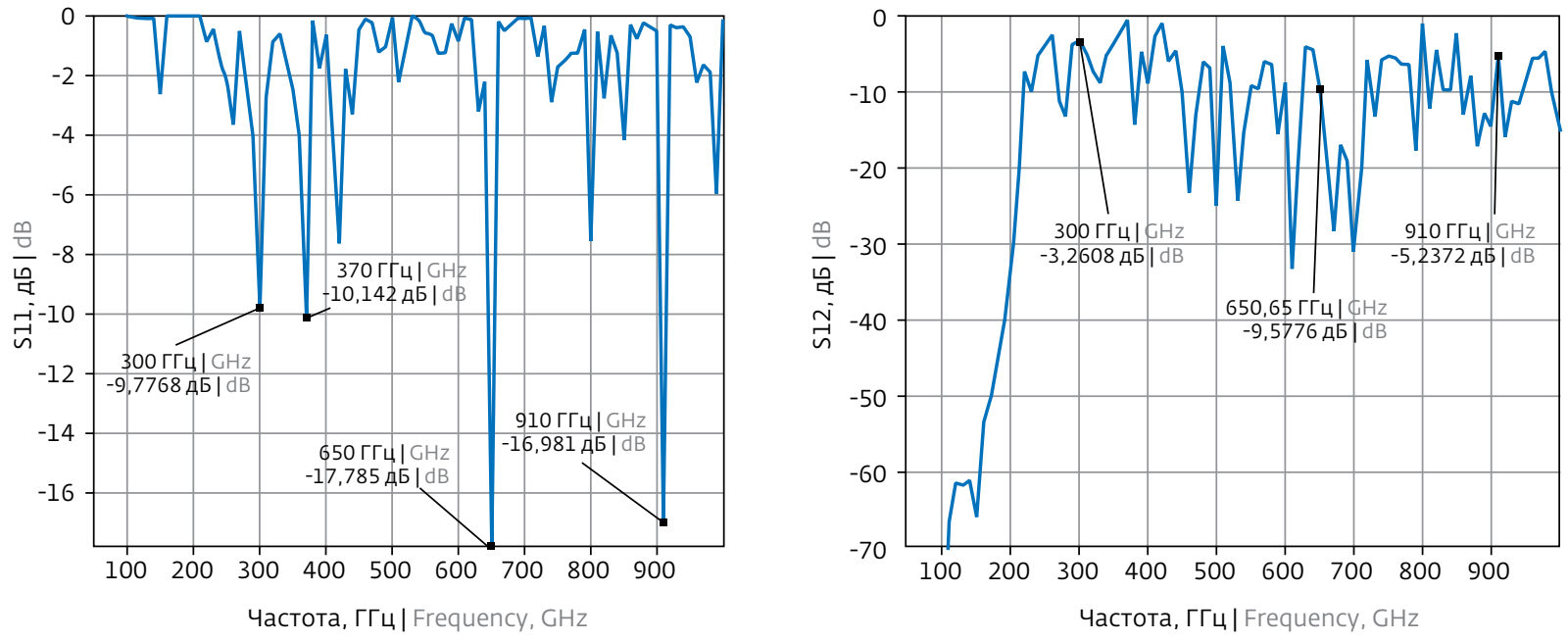

Puc.14. Зависимость S-параметров генератора от частоты

Fig.14. Dependence of S-parameters of generator on frequency

просто. По S-параметрам генератора, измеренным на нескольких частотах, можно определить (или уточнить) элементы его эквивалентной схемы, и, наоборот, известная эквивалентная схема позволяет рассчитать S-параметры на любой частоте диапазона, в котором эта схема корректна.

Для расчетов S-параметров СВЧ-генератора с активным элементом из матрицы нанопроводов использовалась программа EMPro. Результаты представлены на рис.14 и 15. Коэффициент отражения (S11) достигает минимального значения при частоте 650 ГГц. При этой же частоте коэффициент передачи (S12) имеет вполне приемлемое значение около 10 дб. Также имеются локальные минимумы параметра S11 при частотах 300, 370, 910 ГГц и др.

Исходя из анализа зависимости S-параметров генератора от частоты, можно сделать вывод, что оптимальными для его функционирования являются частоты 300, 370, 650 и 910 ГГц. На этих 


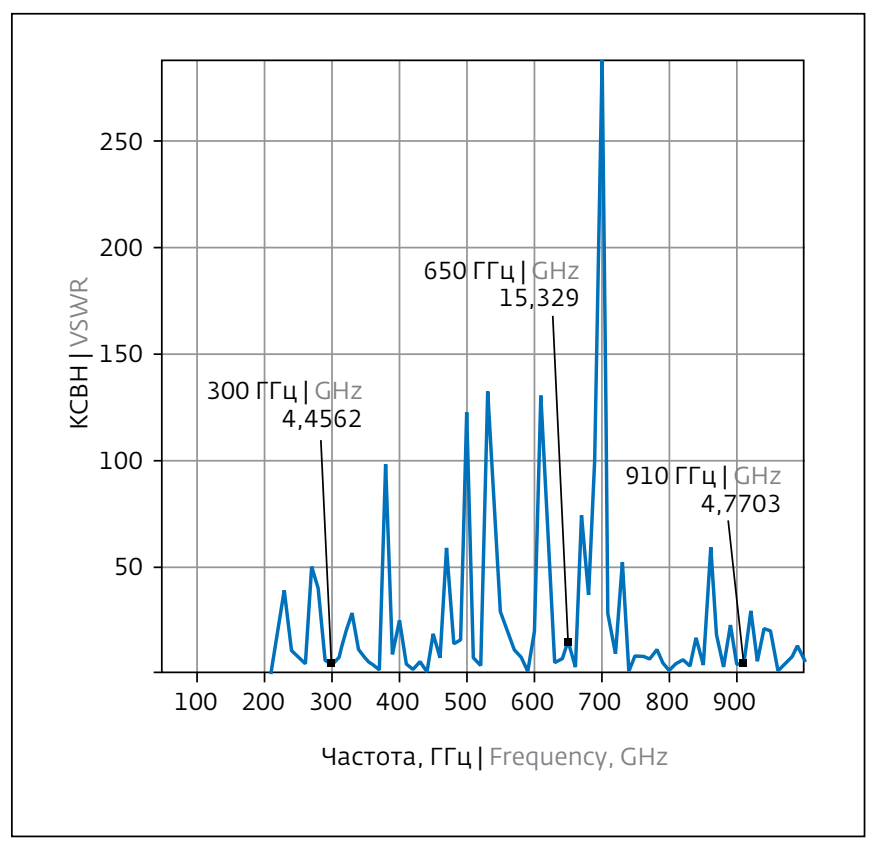

Puc.15. КСBH генератора

Fig.15. VSWR of generator

частотах коэффициент отражения имеет минимумы, коэффициент прохождения - локальные максимумы, а КСВН принимает значения в диапазоне от 4 до 15.

На рис.16 показано распределение электрического поля Е в волноводе на выбранных частотах. На частоте 300 ГГц наибольшая часть мощности выходит в направлении полезной нагрузки, изменение амплитуды происходит равномерно вдоль широкой

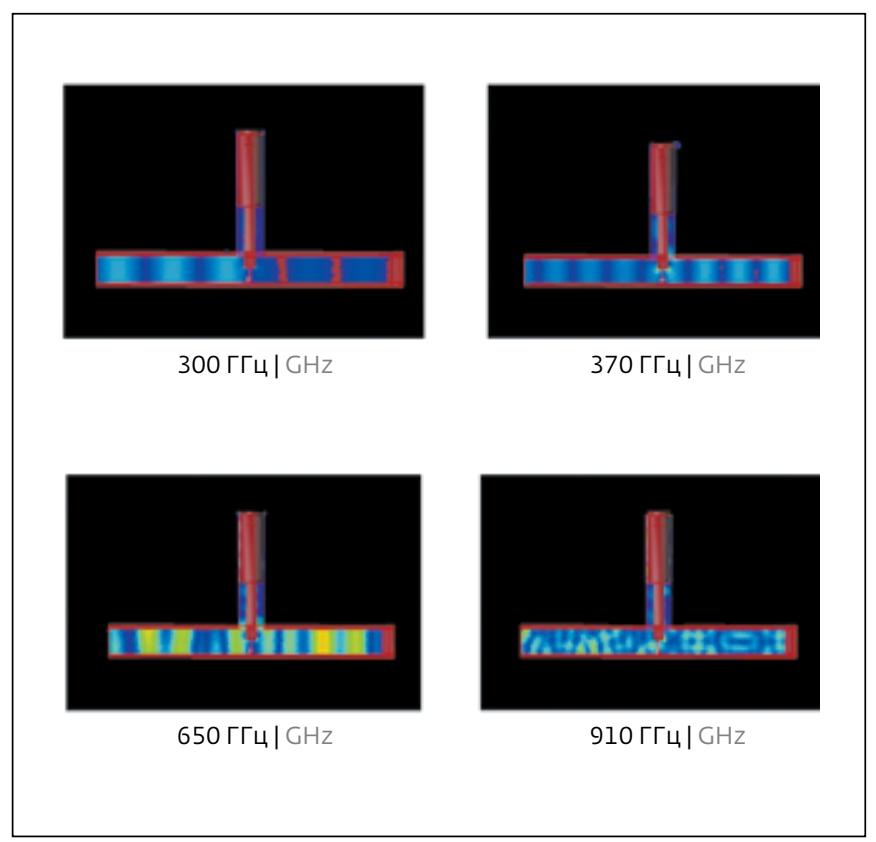

Рис.16. Распределение электрического поля в волноводе генератора при различных частотах генерации

Fig.16. Distribution of electric field in waveguide of generator at different generation frequencies

стенки волновода. При 370 ГГц часть мощности тратится в направлении регулирующего поршня. На частоте 650 ГГц амплитуда поля Е достигает больших значений чем на 300 ГГц, но его распределение вдоль волновода неоднородно. При частоте 910 ГГц образование Е-волн не наблюдается, то есть создать стабильный источник мощности нельзя. the direction of the payload, the amplitude change occurs uniformly along the wide wall of the waveguide. At $370 \mathrm{GHz}$, part of the power is spent in the direction of the regulating piston. At $650 \mathrm{GHz}$, the amplitude of the E-field reaches higher values than at $300 \mathrm{GHz}$, but its distribution along the waveguide is not uniform. At a frequency of $910 \mathrm{GHz}$, the formation of E-waves is not observed, that is, it is impossible to create a stable power source.

\section{CONCLUSION}

Modern technology allows the creation of matrix of InSb nanowires in regular pores of anodic aluminum oxide. The geometric characteristics of the conducting channels vary from $30 \mathrm{~nm}$ to $70 \mathrm{~nm}$ with lengths from $200 \mathrm{~nm}$ to $50 \mu \mathrm{m}$. The planar dimensions of the matrices, in principle, are unlimited. Contacts of nanowires can be created using various metals, semimetals and semiconductors.

In the conducting channels of InSb with dimensions less than $60 \mathrm{~nm}$, already at room temperature, the quantization of the electron energy is realized. The nanowire contacts can be formed in such a way that heterojunctions are formed between them and the conducting channel. When current flows through heterojunctions, various non-equilibrium quantum phenomena are realized that determine the spectrum of possible applications of nanowire matrices.

In particular, generators of electromagnetic oscillations can be created in the frequency range from $300 \mathrm{GHz}$ to $3 \mathrm{THz}$. Theoretical estimates indicate the uniqueness of the characteristics of these promising devices. The first experimental results confirm theoretical predictions. 


\section{ЗАКЛЮЧЕНИЕ}

Современная технология позволяет создавать матрицы нанопроводов из антимонида индия в регулярных порах анодного оксида алюминия. Геометрические характеристики проводящих каналов управляемо варьируются: поперечные сечения в пределах от 30 до 70 нм, а длины от 200 нм до 50 мкм. Планарные размеры матриц, в принципе, ничем не ограничены. Контакты нанопроводов могут быть созданы из различных металлов, полуметаллов и полупроводников.

В проводящих каналах из InSb с размерами, меньшими 60 нм, уже при комнатной температуре реализуется размерное квантование энергии электронов. Контакты нанопроводов могут быть сформированы таким образом, что между ними и проводящим каналом образуются гетеропереходы. При протекании тока через гетеропереходы реализуются различные неравновесные квантовые явления, которые определяют спектр возможных применений матриц нанопроводов.

В частности, могут быть созданы генераторы электромагнитных колебаний в диапазоне частот от 300 ГГц до 3 ТГц. Теоретические оценки свидетельствуют об уникальности характеристик этих перспективных устройств. Первые экспериментальные результаты подтверждают теоретические предсказания.

\section{ЛИТЕРАТУРА}

1. Obukhov I.A. Some aspects of nanoelectronics development in Russia // WTEC Workshop Proceedings: Russian Research and Development Activities on Nanoparticles and Nanostructured Materials. S. Petersburg. 1997. P. 116-125.

2. Datta S. The 21st Century Energy Efficient Logic Transistor // Sematech-2007. Oregon. USA. October $9^{\text {th }}$. 2007. http://www.sematech.org/meetings/ archives/litho/8065/pres/ Key\%20Note\% 20Suman\% 20Datta.pdf.

3. Obukhov I.A. Nonequilibrium effects in onedimensional quantum devices. LAMBERT Academic Publishing, 2014. 132 p.

4. Горох Г.Г. Высокоупорядоченные анодные оксидные пленки алюминия для формирования наноструктур // Сб. ст.: Наноструктурированные оксидные пленки и покрытия. - Петрозаводск: изд-во КГПУ, 2007. С. 62-68.

5. Горох Г.Г., Обухов И.А., Позняк А.А., Лозовенко А.А., Захлебаева А.И., Сочнева Е.А. Синтез нанопроводов InSb в модифицированных матрицах анодного оксида алюминия // Материалы 22-й Международной крымской микроволновой конференции. Севастополь. 2012. Т. 2.С. 655-658.

6. Горох Г.Г., Обухов И.А., Лозовенко А.А., Сочнева Е.А. Темплейтный метод формирования квантовых нанопроводов InSb с большим аспектным отношением // Материалы 23-й Международной крымской микроволновой конференции. Севастополь. 2013. Т. 2.С .820-823.

7. Обухов И.А., Горох Г.Г. Электронные приборы на основе антимонида индия // 22-я Международная крымская конференция "СВЧ-техника и телекоммуникационные технологии" (КрыМиКо'2012): материалы конф., в 2 т., Севастополь, 10-14 сент. 2012 г. Севастополь, 2012. Т.2. С. 653-654.

8. Mozalev A., Gorokh G., Solovei D., Poznyak A. Direct observation of anodic film growth and dissolution on superimposed aluminum and nickel metallic layers // Proceedings of the 13th European Microscopy Congress, (EMC 2004), Belgium, 22-24 Aug. 2004. Gustaaf Van Tendeloo (Ed.) - Antwerp, 2004. P. 533-534.

9. Khan M.I., Penchev M., Jing X., Wang X., Ozkan M., Ozkan C.S., Bozhilov K.N. Electrochemical Growth of InSb Nanowires and Report of a Single Nanowire Field Effect Transistor. Journal of Nanoelectronics and Optoelectronics, 2008. Vol. 3. No. 2. P. 199-202.

10. Горох Г.Г., Обухов И.А., Лозовенко А.А., Захлебаева А.И., Сочнева Е.В. Электрофизические свойства массивов квантовых нанопроводов из InSb // СВЧ-техника и телекоммуникационные технологии: КрыМиКо '2014: Материалы 24-й Междунар. крым. конф., Севастополь, 7-13 сент. 2014 г.: в 2 т. / Изд-во Вебер; Севастополь, 2014. Т. 2. С. 791792.

11. Горох Г.Г., Обухов И.А., Лозовенко А.А. Массивы нанопроводов из антимонида индия для перспективных термоэлектрических устройств // Технология и конструирование в электронной аппаратуре. 2015. № 1.C. 3-11.

12. Das S.R., Delker C.J., Zakharov D., Chen Yo.P., Sands T.D., Janes D.B. Room temperature device performance of electrodeposited insb nanowire field effect transistors // Appl. Phys. Lett. 2011. V. 98. 243504.

13. Обухов И.А. Генерация шума квантовым проводом // Материалы 24-й Международной Крымской Микроволновой Конференции. Севастополь. 2014. Т. 2.С. 798-799.

14. Обухов И.А., Смирнова Е.А. Нанопровод как активный элемент генератора СВЧ излучения // Нано- и микросистемная техника. 2016. Том 18. № 8.С . 509-514. 